\title{
Oligo-Aromatization of Light Hydrocarbons from Petroleum Refining Processes Over ZnO/MFI Microporous Material
}

\author{
IULIEAN V. ASAFTEI ${ }^{1}$, ION SANDU ${ }^{2 *}$, NICOLAE BILBA ${ }^{1 *}$, NECULAI CATALIN LUNGU ${ }^{1}$, \\ MARIA IGNAT ${ }^{1 *}$, ELVIRA MAHU ${ }^{1}$ \\ ${ }^{1}$ Al. I. Cuza University, Faculty of Chemistry, 11 Carol I Blvd, 700506, Iasi, Romania \\ ${ }^{2}$ Al. I. Cuza University, ARHEOINVEST Interdisciplinary Platform, 22 Carol I Blvd, 700506 Iasi, Romania
}

\begin{abstract}
The conversion of light hydrocarbons resulted as by-product of petroleum refining (mixtures of $(n+i)$ butanes, $52.28-63.20$ vol.\%, (1-, cis-, trans-, 2-) butenes, $28.64-36.43$ vol.\% and propane - propylene, $4.79-14.64$ vol.\%) over bifunctional 5\% ZnO/HZSM-5 co-catalyst in a fixed-bed stainless-steel reactor (Twin Reactor System Naky) at 450 C, 4 atm. total pressure and at a space velocity (WHSV) of $1 h^{-1}$ have been investigated. The results indicate that the selectivity to light aromatics - benzene, toluene and xylenes $(B T X)$ - and to both the gaseous $C_{1}, C_{2}-C_{4}$ hydrocarbons and liquid $(i+n) C_{5}-C_{10}$ aliphatic hydrocarbons depends on the time on stream of the process. This is a result of coke deposition (polyunsaturated compounds) and catalyst deactivation. The aromatics BTX represent 59-60 wt\% in the liquid product during the first 24-36 hours time-on-stream and only 20-30 wt\% after 40 hours of reaction when the aliphatic hydrocarbon $C_{5}-C_{10}$ (mostly iso) and $>C_{10}$ (denoted “oligo") reach to $70-80 \mathrm{wt} \%$. The aromatic products were principally toluene, xylenes and benzene, theirs concentration varying with the time on stream of the process. The initial aromatization process described as dehydrocyclodimerization of alkanes and alkenes, principally to aromatics BTX and molecular hydrogen is accompanied by an oligomerization, isomerisation, cracking and alkylation process to form finally in the liquid product an excessively mixture of iso- and normal- $C_{5}-C_{10}$ aliphatic hydrocarbons and $>C_{10}$.
\end{abstract}

Keywords: light hydrocarbons, aromatization, ZnO/HZSM-5, solid-state ion exchange

Light alkanes $\mathrm{C}_{2}-\mathrm{C}_{5}$ are contained in non-associated natural gas (as compressed natural gas) and in associated gas (as petroleum casing-head gas). A considerable amount of $\mathrm{C}_{2}-\mathrm{C}_{4}$ hydrocarbons (alkanes and alkenes) result from petroleum refining processes, especially from destructive technological processes such as catalytic cracking (FCC). The consumption of light gaseous hydrocarbons as feed materials in petrochemical and other syntheses does not exceed $30 \%$ of the overall quantity produced [1].

The most important way to get chemicals with great importance is the direct conversion of lower hydrocarbons (less expensive and abundant) into hydrogen-deficient hydrocarbons (aromatics or alkenes) by catalytic aromatization and oligomerization [2]. The selective transformation of light hydrocarbons $\mathrm{C}_{2}-\mathrm{C}_{4}$ (alkanes and alkenes) into more valuable aromatic - rich liquid hydrocarbons by direct catalytic route is an area of great industrial relevance and also of academic interest for the production of benzene, toluene and xylenes (BTX).

The main reason for the production of aromatics is the application of aromatics as high octane blending components for gasoline (utilization that will grow less and less due to antipollution legislation and because of carcinogenic nature of benzene, especially) [3], as an excellent solvent and a base chemical in a number of petrochemical (as feedstock for rubbers and fibres) and chemical (as commodity chemicals) processes.

The aromatic hydrocarbons are produced from coal by coking (under pyrolitic conditions) and from crude oil by catalytic reforming or hydroforming of heavy naphtha (reformates up to $60-70 \mathrm{vol}$. \%), by naphtha pyrolisis $(5-60$ vol. \% BTX) and by catalytic cracking FCC of naphtha gasoline (with about 25 - 35 vol. \% BTX) [4-6]. The yield of BTX from catalytic processes controlled by thermodynamics (B: $\mathrm{T}: \mathrm{X}=32: 36: 32$, respectively) does not match the marked demand (55: 11: 43) [7]. However, it is well-known that the alkanes have a low reactivity evidenced by theirs standard Gibbs free energy of formation $\left(\Delta \mathrm{G}_{\mathrm{f}}^{0}, 298 \mathrm{~K}\right)$ and the energy (strength) of its $\mathrm{C}-\mathrm{H}$ bonds. The bond energy of $\mathrm{C}-\mathrm{C}$ bond in alkanes is lower than of $\mathrm{C}-\mathrm{H}$ bond, so the $\mathrm{C}-\mathrm{C}$ bond cleavage is more facile compared to $\mathrm{C}-\mathrm{H}$ bond cleavage. On increasing of the carbon number of the alkanes, $\Delta \mathrm{G}_{\mathrm{f}}^{0}\left(\mathrm{~kJ} \mathrm{~mol}^{-1}\right)$ becomes less negative (for n-heptane is yet positive) and the C-H bond energy decreases indicating decreasing stability (440, 423, 413 and $404 \mathrm{~kJ} \mathrm{~mol}^{-1}$ for methane, ethane, propane and n-butane) $[8,9]$. The corresponding alkenes are much more reactive and easy to activate (i.e. $\Delta \mathrm{G}_{\mathrm{f}}^{0}, 298 \mathrm{~K}$ for propylene is $+63 \mathrm{~kJ} \mathrm{~mol}^{-1}$ and $-23.5 \mathrm{~kJ} \mathrm{~mol}^{-1}$ for propane). The overall alkane's aromatization reaction is endothermic as large amounts of molecular hydrogen must be removed. If the feedstock is a mixture of small alkanes and alkenes in a well-defined proportion it is possible that the reaction system to be almost isothermal.

*email: sandu_i03@yahoo.com;n.bilba@yahoo.com; maria.ignat@uaic.ro 
The activation of light alkanes and alkenes is achieved by using high temperatures $\left(\geq 450^{\circ} \mathrm{C}\right)$ and catalysts with acidic and/or dehydrogenating metal (metallic or ionic) sites. The conversion (dehydrocyclodimerization) of light alkanes into aromatics was first described in 1970 by Csicsery [10] using bifunctional catalysts such as $\mathrm{Pt}, \mathrm{Cr}_{2} \mathrm{O}_{3}$, $\mathrm{MnO}_{2}, \mathrm{~V}_{2} \mathrm{O}_{5}, \mathrm{WO}_{3}$ and $\mathrm{MoO}_{3}$ on alumina, but with low selectivity towards aromatics, low conversion and at high temperatures (i.e., $18.7 \%$ conversion for propane at $560^{\circ} \mathrm{C}$ on $\mathrm{Pt} / \mathrm{Al}_{2} \mathrm{O}_{3}$ ). These catalysts were susceptible to coke formed on the catalyst surface resulting in the deactivation.

The most used heterogeneous catalyst in more than 110 industrial processes employed in petroleum refining and petrochemistry are zeolites [11-15]. Zeolites are considered nanomaterials because of their pore sizes that range from 0.3 to $1.0 \mathrm{~nm}$. Zeolites exhibit unique properties with respect to both activity and selectivity. Activity is mostly determined by the zeolite Brönsted acid sites (hydroxyl donating site associated with a negatively charged framework oxygens linked with alumina tetrahedral) and by the active metal - phase supported by zeolite; the selectivity is due to the zeolite micropores and/or cavities size and shape. The major role of acid sites is to function as a proton source for alkanes, leading to the formation of carbocations and for interaction with alkenes ( $\pi$-complex) often resulting in oligomerization. A large number of scientific papers and patents are related to the aromatization of light alkanes and alkenes $\mathrm{C}_{2}-\mathrm{C}_{4}$, of liquefied petroleum gas (LPG) and of light and heavy naphtha [16-29]. Many types of zeolites structures were tested for the aromatization of lower saturated and unsaturated hydrocarbons: ZSM-5 (MFI) [30-79], ZSM-11 (MEL), LTL [80], ZSM-22 (TON), MCM-22 (MWW), BETA (BEA), AlPO ${ }_{4}^{-5}$; -11 (AFI, AEL) and EU-1 (EUO) .

Many studies have focused on the ability of the monofunctional acid catalyst HZSM-5 to convert light hydrocarbons to BTX [18, 19, 21, 23, 25, 33, 39, 51, 73]. HZSM-5 transforms light alkanes and alkenes to products of very similar composition consisting mainly of $\mathrm{C}_{6}-\mathrm{C}_{10}$ aromatics (with low selectivity, about $12 \%$ ) and $\mathrm{C}_{1}-\mathrm{C}_{4}$ aliphatics (especially methane and ethane). This monofunctional acid catalyst offers a preferentially high cracking, isomerization and $\beta$-scission-oligomerization (C-C) reactivity, in addition to dehydrogenation, hydrogen transfer, disproportionation and cyclization reactions. Strong acid sites of HZSM-5 are involved in the two reactions, dehydrogenation and aromatization. Catalytic aromatization of aliphatic hydrocarbons on HZSM-5 catalysts was first described by researchers at Mobil Co. [23] and the production of BTX aromatics as M2-forming ; light alkenes can be converted much faster into aromatics at relatively low temperature $\left(370^{\circ} \mathrm{C}\right)$ whereas light alkanes conversion into alkenes (dehydrogenation) require higher temperature $\left(500-550^{\circ} \mathrm{C}\right)$. The selectivity to aromatics and catalytic activity can be increased significantly by incorporation of transition metals of different size and different chemical features or metal oxide on HZSM-5 zeolite. The extra-framework metal active sites make easy the heterolytic cleavage of the C$\mathrm{H}$ bond of the adsorbed alkanes and accelerate the combination of surface hydrogen and removal as molecular hydrogen. With metal/HZSM-5 catalysts aromatization occurs namely through a bifunctional scheme, metal species catalyzing the dehydrogenation of the alkanes and of the naphthenic intermediates and the acid sites catalyzing the oligomerization of alkenes and the cyclization of oligomers to naphthenes.

The catalysts investigated contain as dehydrogenating metal (metallic, ionic, oxide); gallium [1, 18-25, 28, 30-47, 49, 50], zinc [19-23, 28, 31-36, 43-45, 47, 50-80], platinum [21, 25, 28, 31, 83], cobalt [76], molybdenum [55], nickel, iron [76], copper [65], palladium, ruthenium, rhenium, silver, $\mathrm{Zn}-\mathrm{Ni}, \mathrm{Zn}-\mathrm{Cu}, \mathrm{Zn}-\mathrm{Ga}, \mathrm{Ga}-\mathrm{Pt}, \mathrm{Ga}-\mathrm{In}$. The review of studies showed that only the medium pore zeolites ZSM-5 modified with metals as Ga, Pt, Zn and LTL zeolite in K or $\mathrm{Ba}$ form modified with $\mathrm{Pt}$ or $\mathrm{Zn}$ appear to be the most effective catalysts for alkane / alkene aromatization reaction [17-28].

The conversion of light hydrocarbons $\mathrm{C}_{2}-\mathrm{C}_{4}$ (LPG, light naphtha or light alkenes) into aromatics over HZSM-5, metal $(\mathrm{Ga}$ or $\mathrm{Zn})-\mathrm{HZSM}-5$ and $\mathrm{Pt} / \mathrm{K}(\mathrm{Ba}) \mathrm{L}$ catalysts has been industrially applied using the CYCLAR ${ }^{\mathrm{TM}}$ (BP-UOP) process for converting LPG (also called dehydrocyclodimerization, DHCD) using Ga-doped HZSM-5 catalyst(with butane as feed $65 \% \mathrm{BTX}, 5 \%$ hydrogen and $30 \%$ fuel gas) [81, 82], AROMAX process - Chevron (with $\mathrm{C}_{6}$ to $\mathrm{C}_{8}$ alkanes as feed) [83] and RZ - Platforming (BP-UOP) process to reforms naphtha feed using non-acidic Pt/K(Ba)L catalyst [84], AROFORMING (IFP/Salutec) to aromatize LPG or light naphtha [25], M2-Forming to converts light alkanes and M-Forming process using HZSM-5 [85,86], ALPHA process (Asahi Chemical/Sanyo Petrochemical) to converts olefin-rich hydrocarbons $\mathrm{C}_{4}$ and $\mathrm{C}_{5}$ using Zn-doped HZSM-5 catalyst [72] and Mitsubishi Z-Forming process (light naphtha on HZSM-5) [87].

Platinum exhibit great dehydrogenation capacity of light alkanes and catalytic activity but is expensive and is also active in hydrogenollysis to form unreactive alkanes $\mathrm{C}_{1}$ and $\mathrm{C}_{2}$ and cyclic compounds, which decrease the selectivity to aromatics $[21,25,28,31]$.

Gallium has the advantage over zinc of the lower volatility under reduced atmosphere at high temperature and of the low activity in hydrogenolysis [70].

Zinc ionic and zinc oxide exhibit good dehydrogenation activity and aromatization selectivity but under severe

treatments $\left(>550^{\circ} \mathrm{C}\right)$ zinc metallic can be formed and eluted as $\mathrm{Zn}$ vapours from the catalyst [63]. The use of a zinc modified HZSM-5 instead gallium might be preferential, especially from the environmental point of view owing to the poisonousness and the high price of gallium. The zinc (ionic, metallic or $\mathrm{ZnO}$ )/HZSM-5 catalyst has been made by aqueous ion exchange, incipient wetness impregnation, wet impregnation, chemical vapour deposition, sublimating volatile compounds onto zeolite, solid state reaction (ion exchange involving thermal treatment), by isomorphic 
substitution of framework silicon by zinc during the hydrothermal synthesis or by mechanical mixing of $\mathrm{ZnO}$ with HZSM-5 [26, 51-65].

The purpose of this study is to test the conversion of light hydrocarbons resulted as byproduct of petroleum refining $\left(\mathrm{C}_{3}, \mathrm{C}_{3}=\mathrm{C}_{4}, \mathrm{C}_{4}{ }^{=}\right)$into aromatics over physically mixture ZnO/HZSM-5 co-catalyst.

\section{Experimental part}

Catalyst preparation

NaZSM-5 zeolite was synthesized by hydrothermal crystallization at $180 \pm 5^{\circ} \mathrm{C}$ for $24 \mathrm{~h}$ from alkaline media containing sodium silicate $\left(29.63 \mathrm{wt} . \% \mathrm{SiO}_{2}, 9.55 \mathrm{wt} . \% \mathrm{Na}_{2} \mathrm{O}, 60.82 \mathrm{wt} . \% \mathrm{H}_{2} \mathrm{O}\right.$, pycnometric density $\left.1.443 \mathrm{~kg} \cdot \mathrm{dm}^{-3}\right)$, aluminium sulphate, $\mathrm{Al}_{2}\left(\mathrm{SO}_{4}\right)_{3} \cdot 18 \mathrm{H}_{2} \mathrm{O}$ (15 wt.\% $\mathrm{Al}_{2} \mathrm{O}_{3}$ ), sulphuric acid (96 wt.\%, $1.835 \mathrm{~kg}^{-3}{ }^{-3}$ ), ethylene glycol $\left(1.1132 \mathrm{~kg} \mathrm{dm}^{-3}\right)$ as a gel modifier and as a void filler, deionised water and ammonium hydroxide $\left(25 \mathrm{wt} . \% \mathrm{NH}_{3}\right)$ to control the $\mathrm{pH}$ of the gel $(11.0-11.5)$. All raw materials were used as received.

NaZSM-5 zeolite having a $\mathrm{SiO}_{2} / \mathrm{Al}_{2} \mathrm{O}_{3}$ molar ratio of 41.36 was crystallized from an aqueous gel with molar ratio $\mathrm{SiO}_{2} / \mathrm{Al}_{2} \mathrm{O}_{3}=58.93, \mathrm{Na}_{2} \mathrm{O}$ free $/ \mathrm{SiO}_{2}=0.11$, ethylene glycol$/ \mathrm{SiO}_{2}=0.47$ and $\mathrm{H}_{2} \mathrm{O} / \mathrm{SiO}_{2}=33.44$ in a teflon - lined stainless steel autoclave under static conditions and autogeneous pressure at $180 \pm 5^{\circ} \mathrm{C}$ for 24 hours [88]. The white crystals were filtered, washed thoroughly with deionised water, dried at $110^{\circ} \mathrm{C}$ for 6 hours and finally calcined in flowing air at $500^{\circ} \mathrm{C}$ for 6 hours to remove the organic material. The $\mathrm{Na}$ form obtained was converted into ammonium form, $\mathrm{NH}_{4} \mathrm{ZSM}-5$ by three ion- exchanges with a $1 \mathrm{M}$ fresh solution of ammonium nitrate under reflux at $80^{\circ} \mathrm{C}$ for $6 \mathrm{~h}$ each time (NaZSM-5 $(\mathrm{g}) /$ solution $(\mathrm{mL})=1: 5)$. The solid was then filtered, washed with deionised water, dried in air at $110^{\circ} \mathrm{C}$ for $6 \mathrm{~h}$ and calcined in flowing air at $550^{\circ} \mathrm{C}$ for $6 \mathrm{~h}$, when it was converted in the protonic form, HZSM-5.

The catalyst $\mathrm{ZnO} / \mathrm{HZSM}-5$ used in this study (containing $5 \mathrm{wt} \% \mathrm{ZnO}$ ) was prepared by mechanically mixing the HZSM-5 powder with $\mathrm{ZnO}$ powder(Baker) at room temperature followed by calcination in air at $500^{\circ} \mathrm{C}$ for $6 \mathrm{~h}$. $\mathrm{ZnO} / \mathrm{HZSM}-5$ powder co-catalyst was then pressed, crushed and separated by sieving into grains of $16-32$ mesh.

\section{Physicochemical characterization}

The structure type, phase purity and degree of crystallinity were determined by X-ray powder diffraction pattern which were obtained on a Philips PW 1830 diffractometer using Ni filtered $\mathrm{Cu} \mathrm{K}_{\alpha}$ radiation at a scanning speed of $0.02^{\circ} \mathrm{s}^{-1}$ in the range of $6-32,2 \theta$.

The morphology and size of the individual crystals were obtained by scanning electron microscopy (SEM) with a Microspec WDX-2A using a $25 \mathrm{kV}$ accelerating potential.

The acidity and strength distribution of HZSM-5 and 5\% ZnO/HZSM-5 catalysts were evaluated by using temperature programmed of ammonia desorption (TPD) technique. The samples were activated in a flow of dry $\mathrm{N}_{2}$ at $500^{\circ} \mathrm{C}$ for $4 \mathrm{~h}$ and after cooling to $80^{\circ} \mathrm{C}$ ammonia adsorption were carried out. Physically adsorbed ammonia was removed by degassing in flowing $\mathrm{N}_{2}$ at $100^{\circ} \mathrm{C}$ for $3 \mathrm{~h}$. The amount of ammonia desorbed from $100^{\circ} \mathrm{C}$ to $800^{\circ} \mathrm{C}$ (at the rate of $10^{\circ} \mathrm{C} / \mathrm{min}$ ) was quantitatively monitored volumetrically (absorption in $1 \mathrm{M} \mathrm{HCl}$ ). The ammonia desorbed represents the total acidity (weak and strong) of the sample.

The BET specific surface area applying the BET equation was determined using a Carlo - Erba Sorptomatic Series 1800 instrument at $-196^{\circ} \mathrm{C}$ and at sub-atmospheric pressure with nitrogen as the analysis gas.

\section{Catalyst evaluation}

The performance of the 5\% ZnO/HZSM-5 co-catalyst was tested for light hydrocarbons mixtures (alkanes $\mathrm{C}_{3}, \mathrm{C}_{4}$ and alkenes $\mathrm{C}_{3}=\mathrm{C}_{4}{ }^{=}$) conversion to aromatics BTX in a fixed-bed continuous flow stainless - steel reactor (a commercial Twin Reactor System Naky Metrimpex, Hungary) under $4 \mathrm{~atm}$ total pressure at $450^{\circ} \mathrm{C}$ and at a weight hourly space velocity (WHSV) of $1 \mathrm{~h}^{-1}$. The catalyst was pretreated with $\mathrm{N}_{2}$ for $1 \mathrm{~h}$ at $450^{\circ} \mathrm{C}$ to remove the adsorbed impurities and the moisture.

The reaction products were separated into liquid and gas fractions through an ice - trap. Composition of products was obtained with two gas chromatographs (GC Carlo Erba, model C and Vega) using a fused silica capillary column (25 m length and $0.32 \mathrm{~mm}$ i.d) with SE-52 stationary phase and flame ionization detector (FID) for liquid phase and a column (6 m length) with squalane and dimethyl sulpholane and a thermal conductivity detector (TCD) for gaseous phase, respectively.

\section{Results and discussions}

Structure, morphology, specific surface area and adsorption of ZSM-5 samples

From the diffractogram [33-39], the interplanar distances $\mathrm{d}_{\mathrm{hkl}}$ and the corresponding relative intensities $\left(\mathrm{I} / \mathrm{I}_{0}\right)$ were calculated. The calculated $\mathrm{d}_{\mathrm{hkl}}$ values agree very well with that reported for ZSM-5 (MFI) zeolite [89].

The NaZSM-5 sample has a high crystallinity derived from the high intensities of the XRD lines in the $22.5-25^{\circ}$ (20) range comparatively with a standard ZSM-5 crystallized in presence of tetrapropyl ammonium hydroxide. No other diffraction lines were found in the XRD pattern, which means that only crystalline phase of ZSM-5 zeolite was obtained. The powder-XRD profiles of HZSM-5 and of $5 \mathrm{wt}$. \% ZnO/HZSM-5 (not presented) show that the structure of ZSM-5(MFI) was retained with a slight change in the intensity of the characteristic peaks. The 5 wt.\% $\mathrm{ZnO} /$ 
HZSM-5 co-catalyst exhibit diffraction lines at $2 \theta=31.80^{\circ}, 34.5^{\circ}, 36.4^{\circ}$ and $56.6^{\circ}$ which are characteristic for bulk $\mathrm{ZnO}$ but their intensities are decreased during the thermal activation at $500^{\circ} \mathrm{C}$ indicating a host - guest interaction (solid - state reaction) between Bronsted acid centers of HZSM-5 framework and zinc oxide. SEM image of zeolite NaZSM-5 is shown in Figure 1(b) It reveals the well developed hexagonal - shaped crystals with dimensions of 3.5 $4.3 \mu \mathrm{m}$ in length and $2.1-2.86 \mu \mathrm{m}$ in width. The chemical composition, BET-specific surface area and adsorption properties of NaZSM-5, HZSM-5 and of ZnO/HZSM-5 co-catalyst are presented in Table 1.

Table 1

CHARACTERISTICS OF ZEOLITE SAMPLES AND OF CO-CATALYST [37-39]

\begin{tabular}{|c|c|c|c|c|}
\hline Sample & $\begin{array}{c}\mathrm{SiO}_{2} / \mathrm{Al}_{2} \mathrm{O}_{3} \\
\text { ratio }\end{array}$ & $\begin{array}{c}\text { Zinc loading as } \\
\mathrm{ZnO}, \%\end{array}$ & $\begin{array}{c}\text { BET surface } \\
\text { area, } \mathrm{m}^{2} \mathrm{~g}^{-1}\end{array}$ & $\begin{array}{c}\text { Adsorption of } \\
\text { n-hexane, } \%\end{array}$ \\
\hline NaZSM-5 calcined & 41.36 & & 314.2 & 10.42 \\
\hline HZSM-5 & 41.36 & & 296 & 11.20 \\
\hline ZnO/HZSM-5 & 41.36 & 5.0 & 273 & 10.21 \\
\hline
\end{tabular}

Loading of the Zinc oxide decreases slightly both the BET surface area and adsorption of n-hexane, probably due to pore-size reduction or pore-mouth blockage.

Acidic properties of HZSM-5 and $5 \mathrm{wt} . \% \mathrm{ZnO/HZSM-5}$

Acidic properties of zeolite catalyst are due to the both types of acidic sites (Brönsted and Lewis) and differ by number (mmol $\left.\mathrm{g}^{-1}\right)$, and strength. The total amounts of acid sites calculated from the total amount of $\mathrm{NH}_{3}$ desorption and the acid strength expressed as the maximum temperature desorption of ammonia are summarized in Table 2.

Table 2

TOTAL ACID SITES AND ACID DISTRIBUTION [37-39]

\begin{tabular}{|c|c|c|c|}
\hline \multirow{2}{*}{ Catalyst } & \multirow{2}{*}{$\begin{array}{c}\text { Total acid sites } \\
\mathrm{mmol}^{-1}\end{array}$} & \multicolumn{2}{|c|}{ Acid strength } \\
\cline { 3 - 4 } & & $\mathrm{LT}$ & $\mathrm{HT}$ \\
\cline { 3 - 4 } & & $120-300^{\circ} \mathrm{C}$ & $300-600^{\circ} \mathrm{C}$ \\
\hline $\mathrm{HZSM}-5$ & 1.016 & $0.785\left(208^{\circ} \mathrm{C}\right)$ & $0.231\left(420^{\circ} \mathrm{C}\right)$ \\
\hline $5 \% \mathrm{ZnO} / \mathrm{HZSM}-5$ & 0.862 & $0.720\left(200^{\circ} \mathrm{C}\right)$ & 0.142 \\
\hline
\end{tabular}

The presence of $\mathrm{ZnO}$ and the proton of acidic $\mathrm{OH}$ groups, by thermal activation at $500^{\circ} \mathrm{C}$, caused the decrease of

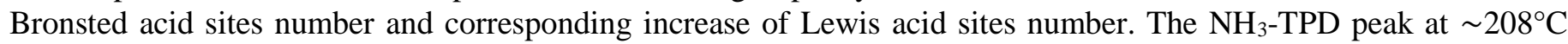
(low temperature, LT) is attributed to the desorption of ammonia from weak acid sites - mostly Lewis acid sites (IR band at $3680 \mathrm{~cm}^{-1}$ ) and the $\mathrm{NH}_{3}$-TPD peak at $\sim 420^{\circ} \mathrm{C}$ (high temperature, HT) to strong acid sites - mostly Brönsted acid sites (IR band at $3610 \mathrm{~cm}^{-1}$ ) and some Lewis acid sites, related to the presence of extra-framework Al-species and zinc oxide species.

\section{Catalytic reactions of light hydrocarbons on $5 \% \mathrm{ZnO/HZSM-5}$}

Before the catalytic tests, the catalyst was heated in reactor at $500^{\circ} \mathrm{C}$ in nitrogen flow for 2 hours. The co-catalyst 5 wt. \% $\mathrm{ZnO} / \mathrm{HZSM}-5$ was evaluated in ten consecutive tests with intermediary regeneration at $500^{\circ} \mathrm{C}$ for $6 \mathrm{~h}$ in nitrogen with $2 \%$ oxygen flow.

Table 3 presents the commercial feedstock composition of each test and operating conditions of aromatization (with intermediate regeneration) on $5 \mathrm{wt}$ \% $\mathrm{ZnO} / \mathrm{HZSM}-5$ co-catalyst.

Table 3

COMPONENTS OF FEEDSTOCK OBTAINED FROM GAS FRACTIONATION UNIT OF A FCC UNIT

\begin{tabular}{|c|c|c|c|c|c|c|c|c|}
\hline \multirow{2}{*}{$\begin{array}{c}\text { Feedstock } \\
\text { comp.(vol.\%) }\end{array}$} & \multicolumn{9}{|c|}{ Test number } \\
\cline { 2 - 9 } & 1 & 2,6 & 3 & 4 & 5 & 7 & 8 & 9,10 \\
\hline $\mathrm{C}_{2}$ & - & 0.16 & 0.67 & 0.97 & 0.20 & 0.12 & 0.30 & 0.23 \\
\hline $\mathrm{C}_{3}$ & 0.13 & 5.36 & 7.17 & 8.65 & 4.16 & 2.18 & 2.69 & 3.81 \\
\hline $\mathrm{C}_{3}=$ & 0.06 & 2.03 & 3.94 & 5.99 & 2.64 & 2.61 & 2.39 & 2.08 \\
\hline $\mathrm{i}_{-}-C_{4}$ & 14.87 & 22.70 & 20.01 & 20.50 & 20.75 & 34.94 & 20.40 & 20.74 \\
\hline $\mathrm{n}-C_{4}$ & 24.94 & 36.58 & 39.35 & 31.54 & 42.45 & 23.47 & 39.19 & 41.86 \\
\hline $\mathbf{\Sigma}(\mathbf{n}+\mathbf{i}) \mathbf{C}_{4}$ & $\mathbf{3 9 . 8 1}$ & $\mathbf{5 9 . 2 8}$ & $\mathbf{5 9 . 3 6}$ & $\mathbf{5 2 . 0 4}$ & $\mathbf{6 3 . 2 0}$ & $\mathbf{5 8 . 4 1}$ & $\mathbf{5 9 . 5 9}$ & $\mathbf{6 2 . 6 0}$ \\
\hline$(1+\mathrm{i}) \mathrm{C}_{4}=$ & 52.89 & 23.44 & 22.89 & 27.06 & 25.09 & 31.44 & 27.46 & 26.87 \\
\hline trans-C $_{4}=$ & 5.54 & 6.70 & 3.95 & 3.22 & 3.47 & 5.03 & 5.79 & 3.35 \\
\hline cis-C $_{4}=$ & 0.88 & 2.90 & 1.80 & 1.44 & 1.60 & 1.50 & 1.50 & 0.65 \\
\hline $\mathbf{\Sigma}(\mathbf{i}+\mathbf{1}+$ tr+cis$) \mathbf{C}_{4}=$ & $\mathbf{5 9 . 3 1}$ & $\mathbf{3 3 . 0 4}$ & $\mathbf{2 8 . 6 4}$ & $\mathbf{3 1 . 7 2}$ & $\mathbf{3 0 . 1 6}$ & $\mathbf{3 6 . 4 7}$ & $\mathbf{3 4 . 7 5}$ & $\mathbf{3 0 . 8 7}$ \\
\hline $1,3-C_{4}==$ & 0.69 & 0.13 & 0.18 & 0.62 & 0.11 & 0.21 & 0.30 & 0.33 \\
\hline
\end{tabular}

Reaction temperature, ${ }^{\circ} \mathrm{C}: 450 ; \mathrm{WHSV}, \mathrm{h}^{-1}: 1$; Pressure, atm: 4; Catalyst, $\mathrm{cm}^{3}: 100$;

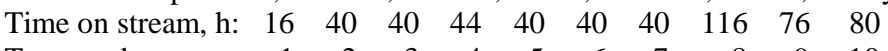

$\begin{array}{lllllllllll}\text { Test number: } & 1 & 2 & 3 & 4 & 5 & 6 & 7 & 8 & 9 & 10\end{array}$ 
The operating conditions (temperature $450^{\circ} \mathrm{C}$, WHSV $1 \mathrm{~h}^{-1}$ and pressure $4 \mathrm{~atm}$ ) were in advance selected to obtain the high yield of liquid product during the catalytic test. The catalytic tests performed over the same sample 5\% ZnO/HZSM-5 co-catalyst differ from one to other only by the composition of the feedstock (except test no. 2 and 6 ) (Table 3). After each test the catalyst was regenerated in nitrogen with $2 \%$ oxygen flow at $500^{\circ} \mathrm{C}$ for 6 hours.

The changes in the composition of gaseous and liquid products resulted over $5 \mathrm{wt} \% \mathrm{ZnO} / \mathrm{HZSM}-5$ co-catalyst with time on-stream (TOS) are presented in figure 1.

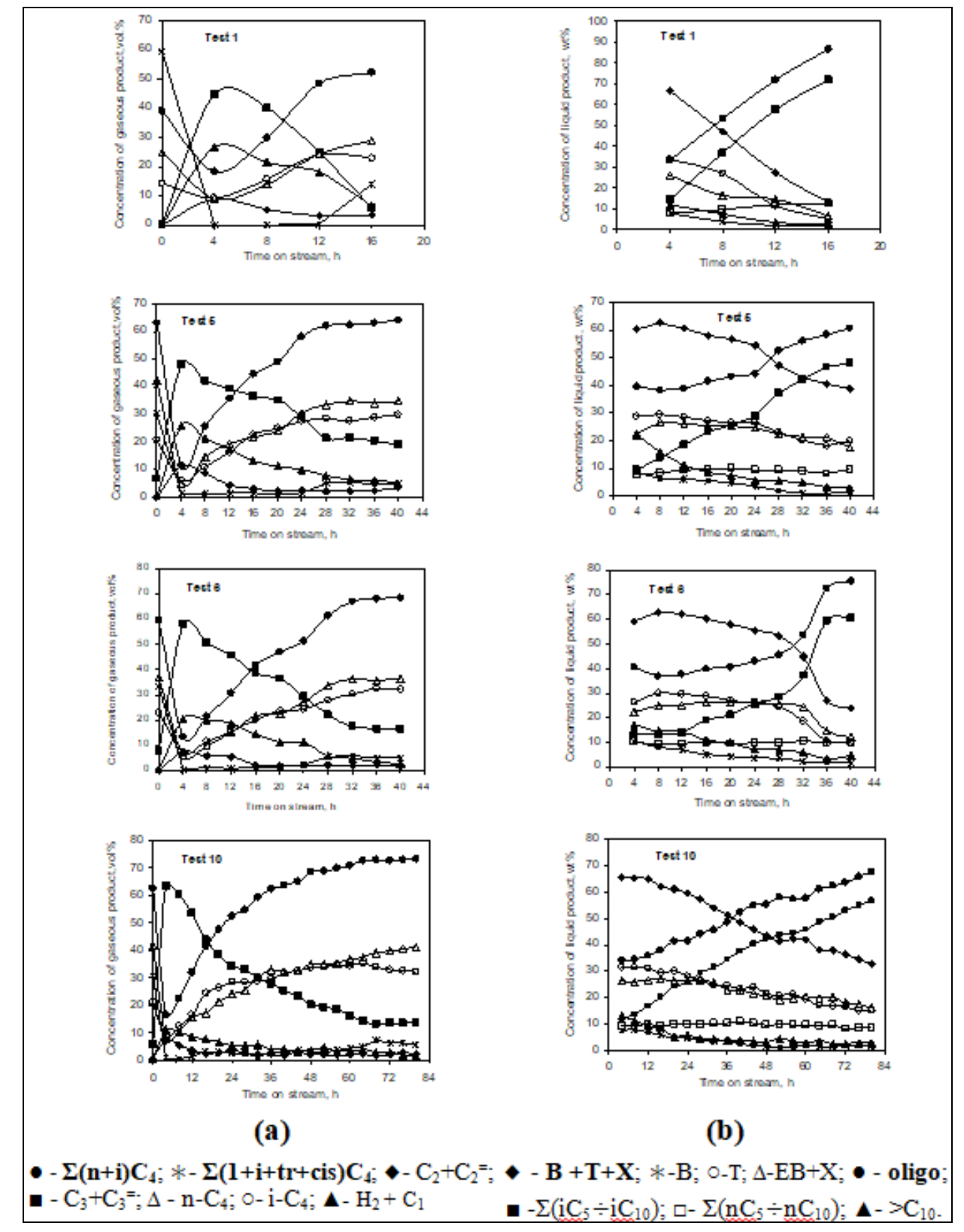

Fig. 1. The gaseous (a) and liquid (b) products distribution resulted from catalytic conversion of commercial feedstock rich in $\mathrm{C}_{4}-\mathrm{C}_{4}=$ hydrocarbons (test number $1,2,5,6,10$ ) over $5 \% \mathrm{ZnO} / \mathrm{HZSM}-5$ co-catalyst $v$ s time-on-stream at $450^{\circ} \mathrm{C}, 4 \mathrm{~atm}$ and $\mathrm{WHSV} 1 \mathrm{~h}^{-1}$

Aromatization of light alkanes and alkenes requires the increase of the chain length up to six carbon atoms and higher as a result of a number of consecutive and paralel reactions including dehydrogenation of alkanes to alkenes, oligomerization of resulted alkenes to dienes, trienes, cyclization of oligomers to naphthenes and dehydrogenation of naphthenes into corresponding aromatic hydrocarbons.

The dehydrogenation of alkanes, $\mathrm{C}_{2}-\mathrm{C}_{4}$ to alkenes, $\mathrm{C}_{2}=-\mathrm{C}_{4}=$ take place as a result of $\mathrm{C}-\mathrm{H}$ bond cleavage with formation of the corresponding alkenes and of hydrogen atom. The existence of $\mathrm{C}$ - $\mathrm{C}$ bonds in alkane, with lower bond energy than $\mathrm{C}-\mathrm{H}$ bond has the possibility to be broken (cracking reaction) with formation of a lighter alkane $\left(\mathrm{C}_{1}, \mathrm{C}_{2}\right)$ and an alkene. This cracking reaction is responsible for the decreasing the total selectivity to aromatics.

The resulted alkenes from cracking and dehydrogenating reactions take part in isomerisation, oligomerization to higher alkenes and dienes, cracking ( $\beta$-scission) and cyclization reactions with particularly formation of naphthenes. The resulted naphthenes are dehydrogenated into respective aromatics and alkanes as a result of hydrogen transfer. 
The conversion of light alkanes and alkenes into aromatics is achieved by using high temperature $\left(500-550^{\circ} \mathrm{C}\right)$ and catalysts with acidic sites (monofunctional, HZSM-5) or with acidic sites and a dehydrogenatic metal (bifunctional, metal ionic, metal oxide/HZSM-5).

The co-catalyst used in this work contains zinc oxide as hydro-dehydrogenating component and molecular sieve ZSM-5 in the hydrogen form as acidic component. Zinc oxide was dispersed on the surface of HZSM-5 by mechanically mixing and heating the mixture at $500^{\circ} \mathrm{C}$. Zinc oxide alone is not active of directly dehydrogenating of propane and butanes but is known as a strong hydrogen adsorbent which prevents hydrogenation of alkenes. The behaviour of $\mathrm{ZnO} / \mathrm{HZSM}-5$ co-catalyst obtained by physically mixture is different than of $\mathrm{ZnO} / \mathrm{HZSM}-5$ obtained by impregnation. Biscardi and Iglesia [23] showed that during impregnation both exchanged zinc cations and extracrystalline $\mathrm{ZnO}$ crystals are formed and the low activity in aromatization of alkanes is due to presence of zinc oxide species that are responsible for blocking the channels of zeolite. Roessner et al. [62] and Heemsoth et al. [64] showed that incorporation of zinc cations by ion exchange or impregnation lead to similar conversion of ethane in aromatics. During the heat treatment of physically mixture $\mathrm{ZnO}+\mathrm{HZSM}-5$ a solid - state reaction between zinc oxide and Brönsted acid sites (strong $\equiv \mathrm{Si}-\mathrm{OH}-\mathrm{Al} \equiv$ and low silanol $\equiv \mathrm{Si}-\mathrm{OH})$ of $\mathrm{HZSM}-5$ yield zinc cations $\left(\mathrm{Zn}^{2+}, \mathrm{ZnO}^{+}\right)$ incorporated in HZSM-5 structure which are active for aromatization of alkanes and alkenes:

$$
\mathrm{ZnO}+2 \mathrm{H}^{+} \cdot \mathrm{OZ} \rightarrow \mathrm{Zn}^{2+}(\cdot \mathrm{OZ})_{2}+\mathrm{H}_{2} \mathrm{O}
$$

Only a small amount of zinc oxide gets into the pores of the zeolite and reacts with the bridging hydroxyl groups. Thanks to this solid-state reaction the strong Brönsted acid site become a strong Lewis acid site. This solid-state reaction was confirmed by Rojasova et al. [58] and Roessner et al. [62].
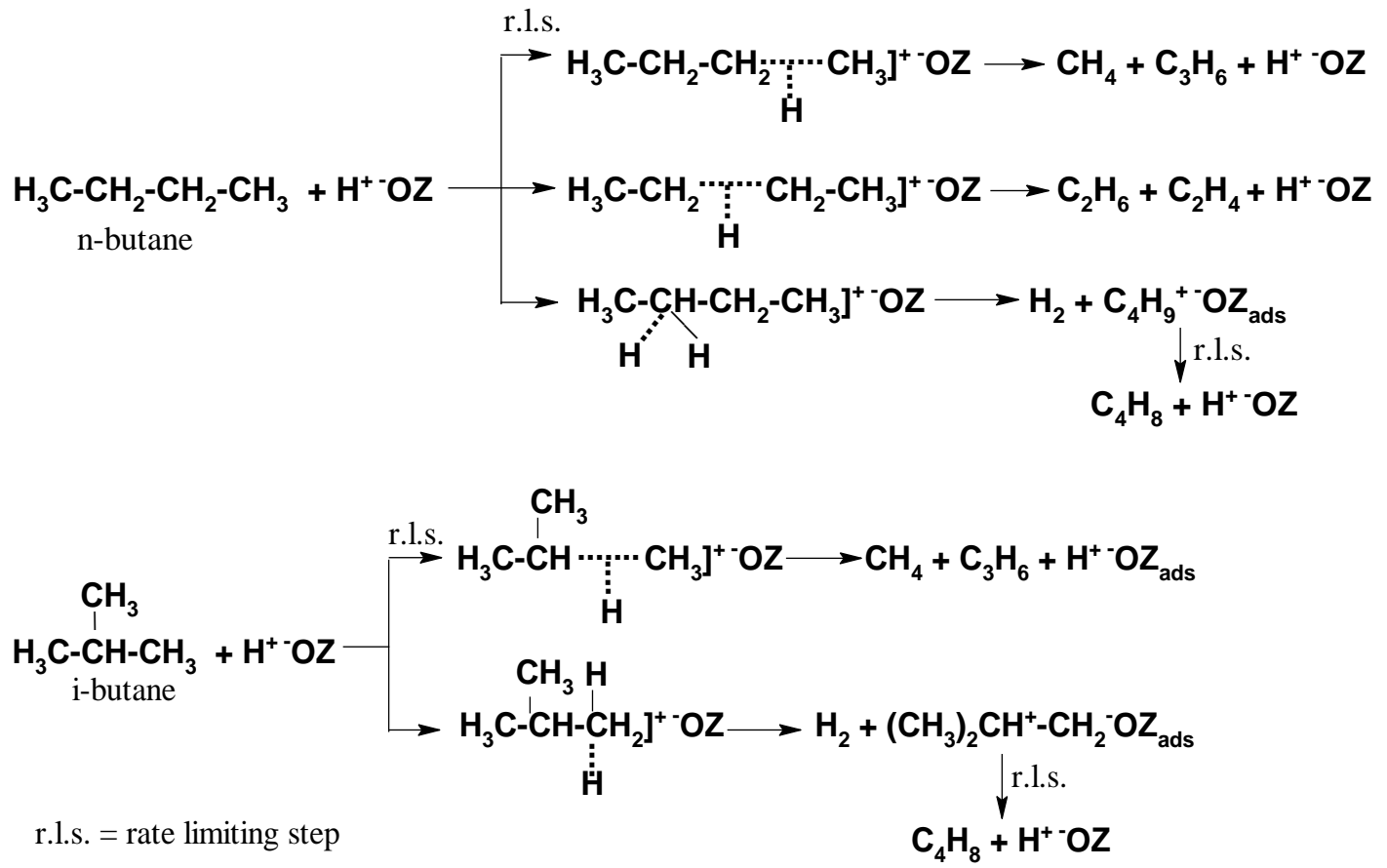

The presence of zinc oxide in the co-catalyst may promote the activation of alkane molecules by a polarization effect of $\mathrm{C}-\mathrm{H}$ bonds and lead to molecular hydrogen formation via recombinative desorption of hydrogen atoms in dehydrogenation reactions.

Alkanes are activated by a monomolecular or a bimolecular [90] mechanism depending on the reaction conditions (temperature, surface concentration of reactants and conversion). According to monomolecular mechanism, the alkane molecule adsorbed on zeolite surface is protonated by a Brönsted acid site under the form of five - coordinated carbon atom (carbonium ion):

The carbonium ion may undergo cracking to yield a lower alkane $\left(\mathrm{CH}_{4}, \mathrm{C}_{2} \mathrm{H}_{6}\right)(\mathrm{r} .2,3,5)$ or to dehydrogenation to yield molecular hydrogen $\left(\mathrm{H}_{2}\right)$ (r. 4 and 6) and of tricoordinated carbenium ion as alkoxide species. The rate limiting step of cracking is the protonation by the Bronsted acid sites and of dehydrogenation it is the alkene desorption from the alkoxide. This alkoxide species may release protons (to regenerate the acid sites of zeolite) to form lower alkenes $\left(\mathrm{C}_{2} \mathrm{H}_{4}, \mathrm{C}_{3} \mathrm{H}_{6}, \mathrm{C}_{4} \mathrm{H}_{8}\right)$ or may take part in hydride transfer beetwen $(\mathrm{n}+\mathrm{i})$ butanes and an alkoxide species with formation of light alkanes and a new alkoxide (r. 7) (a bimolecular mechanism), reaction which may be followed by isomerisation and/or $\beta$-scission : 


$$
\mathrm{C}_{3} \mathrm{H}_{7}^{+-} \mathrm{OZ}+\mathrm{H}_{3} \mathrm{C}-\mathrm{CH}-\mathrm{CH}_{2}-\mathrm{CH}_{3} \longrightarrow \mathrm{C}_{3} \mathrm{H}_{8}+\mathrm{H}_{3} \mathrm{C}-\mathrm{CH}^{+}-\mathrm{CH}_{2}-\mathrm{CH}_{3}^{-} \mathrm{OZ}
$$

The tricoordinated carbenium ion may result too, from alkanes through abstraction of a hydride ion $\left(\mathrm{H}^{-}\right)$by a Lewis acid site present in zeolite structure:<smiles>O[Si](O)(O)O[Si](O)(O)[18O][Si](O)(O)O[Si](O)(O)O</smiles>

The dehydrogenation zinc species are efficient in the increase of aromatization selectivity since they activate the $\mathrm{C}-\mathrm{H}$ bonds and promote the dehydrogenation as well as the migration of hydrogen atom by hydrogen transfer.

At the same time alkenes $\mathrm{C}_{4}=$ react much faster than the alkanes $\mathrm{C}_{4}$ in presence of protonic sites of zeolite yielding the carbenium ions (r.9) which may add to another molecule of alkenes to yield a new carbenium ion (r. 10). It is the case of butenes and propylene existing in the feedstock and resulted from alkane cracking and dehydrogenation:

$$
\begin{aligned}
& \mathrm{H}_{2} \mathrm{C}=\mathrm{CH}-\mathrm{CH}_{2}-\mathrm{CH}_{3}+\mathrm{H}^{+-} \mathrm{OZ} \rightarrow \mathrm{H}_{3} \mathrm{C}-\mathrm{CH}^{+}-\mathrm{CH}_{2}-\mathrm{CH}_{3} \cdot{ }^{-} \mathrm{OZ} \text { ads } \\
& \mathrm{H}_{3} \mathrm{C}-\mathrm{CH}^{+}-\mathrm{CH}_{2}-\mathrm{CH}_{3}+\mathrm{H}_{2} \mathrm{C}=\mathrm{CH}-\mathrm{CH}_{2}-\mathrm{CH}_{3} \rightarrow \mathrm{H}_{3} \mathrm{C}-\mathrm{CH}-\mathrm{CH}_{2}-\mathrm{CH}^{+}-\mathrm{CH}_{2}-\mathrm{CH}_{3} \\
& \mathrm{CH}_{2}-\mathrm{CH}_{3}
\end{aligned}
$$

This carbenium ion can loss a proton $\left(\mathrm{H}^{+}\right)$to form a dimmer in two ways (r. 11 and 12):

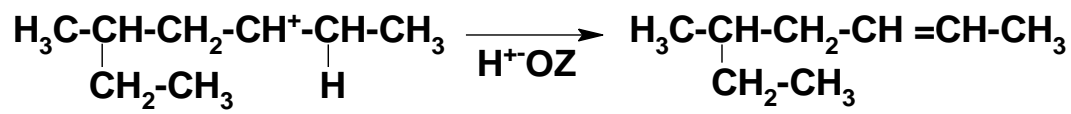

$$
\begin{aligned}
& \text { 5-ethyl-2-hexene }
\end{aligned}
$$

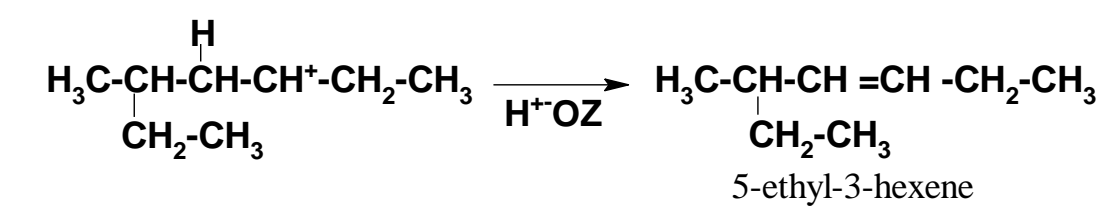

Identically for the propene (r. 13-16):

$$
\begin{aligned}
\mathrm{H}_{3} \mathrm{C}-\mathrm{CH}=\mathrm{CH}_{2}+\mathrm{H}^{+}\left(\mathrm{H}^{+-} \mathrm{OZ}\right) \underset{\text { isopropyl carbocation }}{\mathrm{H}_{3} \mathrm{C}-\mathrm{CH}^{+}-\mathrm{CH}_{3}} \\
\mathrm{H}_{3} \mathrm{C}-\mathrm{CH}^{+}-\mathrm{CH}_{3}+\mathrm{H}_{2} \mathrm{C}=\mathrm{CH}-\mathrm{CH}_{3} \longrightarrow \mathrm{H}_{3}^{\mathrm{C}-} \underset{\mathrm{CH}-\mathrm{CH}_{2}-\mathrm{CH}^{+}-\mathrm{CH}_{3}}{\mathrm{CH}_{3}}
\end{aligned}
$$

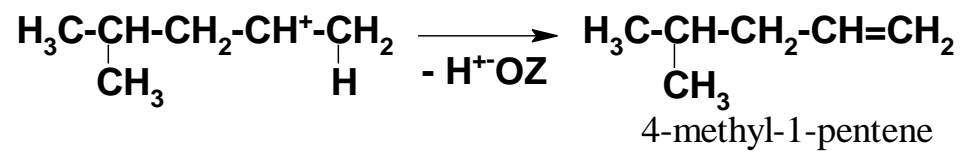

$$
\underset{\mathrm{CH}_{3} \mathrm{H}}{\mathrm{H}} \mathrm{C}-\mathrm{CH}-\mathrm{CH}-\mathrm{CH}^{+}-\mathrm{CH}_{3} \underset{-\mathrm{H}^{+} \mathrm{OZ}}{\stackrel{\mathrm{H}}{\mathrm{H}} \mathrm{C}-\mathrm{CH}-\mathrm{CH}}=\underset{\mathrm{CH}_{3}}{\mathrm{C}}-\mathrm{CH}-\mathrm{CH}_{3}
$$

Once formed, the alkenes rapidly proceed to protonic cracking, isomerisation, oligomerization, dehydrogenation to diene, cyclization to naphthenes and aromatization by dehydrogenation of naphthenes.

Zinc cations and $\mathrm{ZnO}$ can promote heterolytic cleavage of $\mathrm{C}-\mathrm{H}$ bonds to give a transitient species of the type [Zn$\mathrm{H}]^{+}(26,31,66)$ and to decrease the $\mathrm{C}-\mathrm{C}$ bond cleavage: 


$$
\begin{aligned}
& \mathrm{H}_{3} \mathrm{C}-\mathrm{CH}_{2}-\mathrm{CH}_{2}-\mathrm{CH}_{3}+\mathrm{Zn}^{2+} \longrightarrow \mathrm{H}_{3} \mathrm{C}-\mathrm{CH}^{+}-\mathrm{CH}_{2}-\mathrm{CH}_{3}+[\mathrm{Zn}-\mathrm{H}]^{+} \\
& \mathrm{H}_{3} \mathrm{C}-\mathrm{CH}_{2}-\mathrm{CH}_{2}-\mathrm{CH}_{3}+\mathrm{Zn}^{2+} \longrightarrow \begin{array}{l}
\longrightarrow \mathrm{H}_{3} \mathrm{C}-\mathrm{CH}^{+}-\mathrm{CH}_{3}+\left[\mathrm{Zn}-\mathrm{CH}_{3}\right]^{+} \\
\longrightarrow \mathrm{H}_{3} \mathrm{C}^{+} \mathrm{CH}_{2}^{+}+\left[\mathrm{Zn}-\mathrm{CH}_{2}-\mathrm{CH}_{3}\right]^{+}
\end{array}
\end{aligned}
$$

The surface species $[\mathrm{Zn}-\mathrm{H}]^{+},\left[\mathrm{Zn}-\mathrm{CH}_{3}\right]^{+}$and $\left[\mathrm{Zn}-\mathrm{CH}_{2}-\mathrm{CH}_{3}\right]^{+}$are immediately scavenged by protons $\left(\mathrm{H}^{+}\right)$of zeolite resulting molecular hydrogen, methane and ethane :

$$
\begin{aligned}
& {[\mathrm{Zn}-\mathrm{H}]^{+}+\mathrm{H}^{+} \longrightarrow \mathrm{Zn}^{2+}+\mathrm{H}_{2}} \\
& {\left[\mathrm{Zn}-\mathrm{CH}_{3}\right]^{+}+\mathrm{H}^{+} \longrightarrow \mathrm{Zn}^{2+}+\mathrm{CH}_{4}} \\
& {\left[\mathrm{Zn}-\mathrm{CH}_{2}-\mathrm{CH}_{3}\right]^{+}+\mathrm{H}^{+} \longrightarrow \mathrm{Zn}^{2+}+\mathrm{C}_{2} \mathrm{H}_{6}}
\end{aligned}
$$

Zinc in cationic exchange positions is stable and remain unreduced during the aromatization of alkanes and alkenes when molecular hydrogen is present [76]. Zinc oxide is possible to gradually be reduced to the zinc metal and to vaporize at the high operating temperatures $\left(500-600^{\circ} \mathrm{C}\right)$ which led to an irreversible decline in the aromatization [63, 70]. To avoid the volatilization of zinc we performed experiments at high pressure (4 at) and at a temperature $\left(450^{\circ} \mathrm{C}\right)$ below to melting point of zinc metal.

In accordance with the results plotted in Fig. 1 the catalytic activity of the co-catalyst $5 \mathrm{wt} \% \mathrm{ZnO} / \mathrm{HZSM}-5$ in the test no. 1 is different from the other one. Although the feedstock contain more alkenes $\mathrm{C}_{4}=(59.31 \mathrm{vol} . \%)$ than alkanes $(\mathrm{n}+\mathrm{i}) \mathrm{C}_{4}(39.81 \mathrm{vol} . \%)$ the aromatics formation is maximum at 4 hours TOS $(66.65 \mathrm{wt} \%$ BTX and $33.35 \mathrm{wt} \%$ ( $\mathrm{i}+$ n) $\mathrm{C}_{5}-\mathrm{C}_{10}$ and $>\mathrm{C}_{10}$ in the liquid product) after that decreased quickly in the favour of oligomerization (12.98 wt $\%$ BTX and $86.79 \mathrm{wt} \%(\mathrm{i}+\mathrm{n}) \mathrm{C}_{5}-\mathrm{C}_{10}$ and $\left.>\mathrm{C}_{10}\right)$ after $16 \mathrm{~h}$ of reaction. During the first 4 hours of reaction, the concentration of butenes attain zero and of $(\mathrm{n}+\mathrm{i})$ butanes decreased from $39.30 \mathrm{vol} . \%$ to $18.26 \mathrm{vol}$. \%. In the gaseous product the new hydrocarbons are propane, ethane and methane as a result of cracking and hydrogen transfer. After that the concentration of $(\mathrm{n}+\mathrm{i})$ butanes is growing and after $12 \mathrm{~h}$ or reaction become higher than in the feedstock. The aromatization activity of the co-catalyst is reduced because of coke forming.

The behaviour of the co-catalyst ZnO/HZSM-5 after the first test of reaction and regeneration (in nitrogen with 2 vol. $\%$ oxygen flow at $500^{\circ} \mathrm{C}$ for $6 \mathrm{~h}$ ) was different from the test no.1. This time, the feedstock contains more alkanes $\mathrm{C}_{3}, \mathrm{C}_{4}\left(59.28 ; 63.20 ; 62.60\right.$ vol. \%) than alkenes $\mathrm{C}_{3}=\mathrm{C}_{4}=(33.04 ; 30.16 ; 30.87$ vol. \% $)$. As a consequence of the initial heat treatment, of catalytic process (test no.1) and of regeneration, changes take place in the distribution of zinc species because of solid-state reaction between zinc oxide and Brönsted acid sites with changing in strong Lewis acid sites (aprotic strong acid sites) more active in dehydrogenation. In addition to this is possible to have isomorphic substitution of aluminium with zinc in the network and reaction with free alumina or silica. For this reason the aromatization activity was extended to $24-36 \mathrm{~h}$ (test no. 2, 5, 6, 10, Figure1) when in the liquid product the BTX represent $59-60$ wt. \% in the average.After $24-36 \mathrm{~h}$ the aromatization activity decreased in the favour of oligomerization, izomerization and hydrogen transfer without cyclization. Therefore, the liquid product contain more oligo hydrocarbons, a mixture of aliphatic hydrocarbons of the composition $\mathrm{C}_{5}-\mathrm{C}_{10}$ mostly branched $\left(\mathrm{iC}_{5}-\mathrm{iC}_{10}\right)$, than aromatic BTX $(86.97 \mathrm{wt} \%$ after $16 \mathrm{~h}$ - test no. 1 vs. $12.98 \mathrm{wt} \% ; 79.05 \mathrm{wt} \%$ after $40 \mathrm{~h}-$ test no. 2 vs. $20.41 \mathrm{wt} \%$; $60.71 \mathrm{wt} \%$ after $40 \mathrm{~h}$-test no. 5 vs. $39.05 \mathrm{wt} \% ; 75.59 \mathrm{wt} \%$ after $40 \mathrm{~h}$ - test no. 6 vs. $23.58 \mathrm{wt} \% ; 67.65 \mathrm{wt} \%$ after $80 \mathrm{~h}$.

The octanic number and density of the liquid resulted in each test are summarized in Table. 4

Table 4

OCTANIC NUMBER AND DENSITY OF LIQUID PRODUCT

\begin{tabular}{|c|c|c|c|c|c|}
\hline \multirow{2}{*}{ Characteristics } & \multicolumn{5}{|c|}{ Test number } \\
\cline { 2 - 6 } & 1 & 2 & 5 & 6 & 10 \\
\hline Density, $\mathrm{g} / \mathrm{cm}^{3}$ & 0.796 & 0.798 & 0.808 & 0.809 & 0.800 \\
\hline MON & 100 & 100 & 104 & 103 & 103 \\
\hline
\end{tabular}

For comparison the liquid obtained by the aromatization process of a mixture of gaseous hydrocarbon (56 vol\% $(\mathrm{n}+\mathrm{i}) \mathrm{C}_{4}$ and $\left.41.63 \mathrm{vol} \% \mathrm{C}_{4}{ }^{=}\right)$on HZSM-5 catalyst at 8 at and $450^{\circ} \mathrm{C}$ contain after $4 \mathrm{~h}$ TOS only $51.5 \mathrm{wt} \%$ BTX [63].

During the reaction, alkenes from feedstock activate the dehydrogenation of alkanes but after $24-36 \mathrm{~h}$ TOS the alkanes carry out the role of diluents and their concentration exceed the concentration of feedstock. The alkenes $\mathrm{C}_{4}{ }^{=}$ are wholly consumed during the first $24 \mathrm{~h}$ TOS, after that, especially the concentration of $(1+\mathrm{i}) \mathrm{C}_{4}=$ begin to increase.

The alkanes $(n+i) C_{4}$ consumption reach the maximum after first $4 \mathrm{~h}\left(85 \%\right.$ for $n-C_{4}$ and $65 \%$ for $\left.\mathrm{i}-\mathrm{C}_{4}\right)$. Further their concentration is growing up and after $24-32 \mathrm{~h}$ TOS become higher than in the feedstock, especially of i-butane.

In the gaseous product the main components are propane $\gg$ methane $\gg$ ethane, theirs concentrations decreasing continuous with TOS. Presence of molecular hydrogen is a result of dehydrogenation and of hydrogen transfer. 
The loss of catalytic activity with the reaction progress is a result of the decreasing of the number of active sites upon coke deposition.

The dehydrogenating activity ( $\mathrm{C}-\mathrm{H}$ bond cleavage) of ZnO/HZSM-5 co-catalyst via zinc species in the first 4 hours TOS is overcome by the protolytic cracking activity (C-C bond cleavage) when dehydrogenation via acid sites of HZSM-5 involves hydrogen transfer with the formation of low molecular-mass alkanes.

\section{Conclusions}

The dispersion and incorporation of $\mathrm{ZnO}$ in the HZSM-5 zeolite was successfully carried out by the physical mixing followed by heat treatment when the solid - state ion exchange of zinc oxide and Brönsted acid sites take place and zinc cations are present together with zinc oxide.

The preparation method by physical mixture is easy in formulation, safe, lower in cost and environmentally friendly.

Zinc species working synergetically with the Brönsted and Lewis acid sites of the zeolite are responsible for the dehydrogenation of alkanes $\left(C_{3},(n+i) C_{4}\right)$ to alkenes $C_{2}=-C_{4}=$, alkene oligomers $C_{4}=-C_{10}=$ to dienes $C_{4}={ }^{\prime}-C_{10}==$ and of naphthenes cyclo $\mathrm{C}_{6}-\mathrm{C}_{10}$ to aromatics $\mathrm{C}_{6}-\mathrm{C}_{10}$ and Brönsted and Lewis acid sites are responsible for the isomerisation of $n-C_{4}=$ to $i-C_{4}=$, oligomerization of $C_{2}=-C_{4}=$ to $C_{4}=C_{10}=$ and cyclization of dienes $C_{4}={ }^{\prime}-C_{10}==$ to naphthenes cyclic $-\mathrm{C}_{6}-\mathrm{C}_{10}$.

The addition of zinc oxide in HZSM-5 influence the distribution of the acid sites reducing the number of the strong Brönsted acid sites (as proton donors and forming both carbonium and carbenium ions) with medium Lewis acid sites (as electron pair acceptor and forming only carbenium ions).

The aromatization of mixtures of short alkanes $\left(\mathrm{C}_{3}, \mathrm{C}_{4}\right)$ and alkenes $\left(\mathrm{C}_{3}{ }^{=}, \mathrm{C}_{4}{ }^{=}\right)$over bifunctional 5 wt $\%$ $\mathrm{ZnO} / \mathrm{HZSM}-5$ co-catalyst is a complex process, involving a large number of consecutive and parallel reactions. To avoid the reduction and volatilization of zinc we performed experiments at 4 at total pressure, at $450^{\circ} \mathrm{C}$ and a WHSV of $1 \mathrm{~h}^{-1}$.

The catalytic activity is changing with time-on -stream; the aromatics BTX represent $59-60 \mathrm{wt} \%$ in the liquid product during the first $24-36 \mathrm{~h}$ TOS after that their concentration is decreased to $20-30 \mathrm{wt} \%$ at $40 \mathrm{~h}$ TOS.

The dehydrogenation activity of the zinc species in the dehydrogenation of $(n+i)$ butanes reached a maximum during first $4 \mathrm{~h}$ TOS and after $24-32 \mathrm{~h}$ TOS their concentration become higher than in the feedstock and the process is based only on the conversion of alkenes.

High reactant pressure, high conversion and low temperature favour the reactions in the bimolecular mechanism; the formation in principal of propane in the gaseous product is a result of hydride transfer between a butane molecule and a dimethylcarbenium ion.

In the liquid product the concentration of aliphatic hydrocarbons $\mathrm{C}_{5}-\mathrm{C}_{10}$ (mostly iso) and $>\mathrm{C}_{10}$ (denoted "oligo") is increasing up to $70-80 \mathrm{wt} \%$ after $40 \mathrm{~h}$ TOS.

\section{References}

1. MINACHEV, K.M., DERGACHEV, A.A., Russ. Chem. Bull., 47, No. 6, 1998, p. 1037. LANGE J.P., Economics of alkane conversion, in: Sustainable strategies for the upgrading of natural gas: Fundamentals, challenges and opportunities, Springer, E.G. Derouane, V. Parmon, F. Lernos, F.R. Ribeiro (Eds.), 2005, p. 51-83.

3. MATAR, S., HATCH, L.F., Chemistry of Petrochemical Processes, 2nd edition, Gulf Publishing (Butterworth - Heinemann) USA, 2001, p. 262-300.

4. RIGUTTO, M.S., van VEEN, R., HUVE, L., Zeolites in hydrocarbon processing, in: Stud. Surf. Sci. Catal., 168, chapter 24, 2007, p. 855-913.

5. WEISSERMEL, K., ARPE, H.J., Industrial organic chemistry, Aromatics - Production and Conversion, $4^{\text {th }}$ ed. VGH, Weinheim, 2003, Chap. 12 p. $313-336$.

6. DEHERTOG, W.J.H., FROMEN, G.F., Appl. Catal. A:General, 189, No.1, 1999, p.63.

7. ROMERO, F.J., ROLDAN, R., JIMENEZ, C., BORAU, V., MARINAS, J.M., Appl. Catal. A: General, 266, 2004 , p. 203.

8. TRAA, Y., Non-oxidative activation of light alkanes on solid catalysts, $3^{\text {rd }}$ Intern. Workshop Inside Pores, New challenges for nanoporous materials, Alicante, Spain, sept. 24-26, 2007.

9. BLANSKBY, S.J., ELLISON, G.B., Acc. Chem. Res., 36, 2003, p. 255.

10. CSICSERY, S.M., J. Catal., 17,No.2, 1970, p.207; p.216; J. Catal., 17, No.3, 1970, p. 315; J. Catal., 18, No. 1, 1970 , p. 30.

11. MARCILLY, C., Evolution of Refining and Petrochemicals: What is the place of zeolites, Oil\&Gas Sci. Technol., Rev. IFP, 56, No.5, 2001, p. 499; Zeolites in Petroleum Industry, Encyclopedia of Supramolecular Chemistry, 1, 2004, p. 1599-1609.

12. DYER, A., Zeolites, in: Encyclopedia of Inorganic Chemistry, King R.B. Ed., John Wiley \& Sons, Chichester, 1994 , vol. 8, p. 4363-4391

13. VENUTO, P.B., Micropor. Mat., 2, 1994, p. 297.

14. VENUTO, P.B., HABIR, E.T., Catal. Rev. Sci Eng., 18, No. 1, 1978, p. 1.

15. CORMA, A.A., MARTINEZ, A., Stud. Surf. Sci. Catal., 157, 2005, p. 337.

16. O'CONNOR, C.T., Aromatization of light alkanes, in: Handbook of Heterogeneous Catalysis, Eds. Knözinger, Schüth, Weitkamp, WileyVCH Verlag GmbH\&Co, 2008, p. 3123-3133.

17. Al-ZAHRANI, S.M., Chem. Eng., 6, No.1-2, 2008, p. 101.

18. BHAN, A., DELGASS, W.N., Catal. Rev. Sci. Eng., 50, No. 1, 2008, p. 19.

19. CAEIRO, G. CARVALHO, R.H., WANG, X., LEMOS, M.A.N.D.A., LEMOS, F., GUISNET, M., RIBEIRO, F.R., J. Molec. Catal. A:

Chemical, 255, No.1-2, 2006, p. 131.

20. FRICKE, R., KOSSLICK, H., LISCHKE, G., RICHTER, M., Chem. Rev., 100, No.6, 2000 , p. 2303.

21. MERIAUDEAU, P., NACCACHE, C., Catal. Rev. Sci. Eng., 39, No. 1-2, 1997, p. 5.

22. HAGEN, A., ROESSNER, F., Catal. Rev., 42, No. 4, 2000, p. 403.

23. BISCARDI, J.A., IGLESIA, E., Catal. Today, 31, 1996, p. 207-; J. Phys. Chem., 102, 1998 B, p. 9284.

Rev. Chim. $71 \diamond$ no. $2 \diamond 2020 \diamond$ http://revistadechimie.ro 
24. GIANNETTO, G., MONQUE, R., GALIASSO, R., Catal. Rev. Sci. Eng., 36, No. 2, 1994, p. 271.

25. GUISNET, M., GNEP, N.S., ALARIO, F., Appl. Catal. A: General, 89, No. 1, 1992, p. 1.

26. ONO, Y., Catal. Rev. Sci. Eng., 34, No. 3, 1992, p. 179.

27. ONO, Y., KITAGAWA, H., SENDODA, Y., J. Chem. Soc., Faraday Trans., 83, No.1, 1987, p. 2913.

28. SEDDON, D., Catal. Today, 6, 1990, p. 351.

29. LU, H., YOU, H., Petroleum Sci. Technol., 28, No.8, 2010, p. 816.

30. KITAGAWA, H., SENDODA, Y., ONO, Y., J. Catal., 101, 1986, p. 12.

31. INUI, T., MAKINO, Y., OKAZUMI, F., MIYAMOTO, A., Stud. Surf. Sci. Catal., 37, 1987, p. 487.

32. . INUI, T., MAKINO, Y., OKAZUMI, NAGANO, S., MIYAMOTO, A., Ind. Eng. Chem. Res., 26, No.4, 1987, p.647.

33. SCURRELL, M.S., Appl. Catal., 41, 1988, p. 89.

34. BERTI, G., MOORE, J.E., SALUSINSKY, L., SEDDON, D., Aust. J. Chem., 42, 1989, p. 2095.

35. ONO, Y., NAKATANI, H., KITAGAWA, H., SUZUKI, E., Stud. Surf. Sci. Catal., 44, 1989, p. 279.

36. ASAFTEI, I.V., EARAR, K., BIRSA, L.M.., SANDU, I.G., LUNGU, N.C.L., SANDU, I., Rev. Chim., 66, no. 7, 2015 , p. 963.

37. ASAFTEI, I. V., BILBA, N., SANDU, I., Rev. Chim., 65, No.6, 2014, p.697.

38. ASAFTEI, I. V., BILBA, N., SANDU, I., Rev. Chim., 64, no.8, 2013, p.838.

39. ASAFTEI, I.V., SANDU, I., LUNGU, N.C., SPAC, A.F., IGNAT, M., Rev. Chim., 69, no.4, 2018, p.938.

40. IGLESIA, E., BAUMGARTNER, J.E., Catal. Lett., 21, 1993, p. 55.

41. DOOLEY, K.M., PRICE, G.L., KANAZIREV, V.I., HART, V.I., Catal. Today, 31, No. 3-4, 1996, p. 305.

42. MERIAUDEAU, P., NACCACHE, C., Catal.Today, 31, No. 3-4, 1996, p. 265.

43. ASAFTEI, I.V., SANDU, I.G., BIRSA, L.M., MANEA, LILIANA, ROZEMARIE, EARAR, K., Rev. Chim., 66, no.3, 2015 , p.336

44. MAFTEI, D., ASAFTEI, I. V., SANDU, I., MANEA, LILIANA, ROZEMARIE, BIRSA, L.M., EARAR, K., Rev. Chim., 66, no. 5, 2015, p. 673.

45. VISWANADHAM, N., MURALIDHAR, G., PRASADA RAO, T.S.R., J. Molec. Catal. A: Chemical, 223, No. 1-2, 2004 , p. 269.

46. LUKYANOV, D.B., VAZHNOVA, T., Appl. Catal. A: General, 316, No. 1, 2007, p. 61-67.

47. SUBBOTINA, I.R., KAZANSKY, V.B., Petroleum Chemistry, 49, no. 1, 2009, p. 11-15.

48. GUISNET, M., GNEP, N.S., AITTALEB, D., DOYEMET, Y.J., Appl. Catal. A:General, 87, No.2, 1992, p. 255.

49. NISHI, K., KOMAI, S., INAGAKI, K., SATSUMA, A., HATTORI, T., Appl. Catal. A: General, 223, 2002, p. 187.

50. NGUEN, L.H., VAZHNOVA, T., KOLACZKOWSKI, S.T., LUKYANOV, D.B., Chem. Eng. Sci., 61, 2006, p. 5881.

51. MOLE, T., ANDERSON, J.R., CREER, G., Appl. Catal. A: General, 17, 1985, p. 141.

52. KANAI, Y., KAWATA, N., J. Catal., 114, No.2, 1988, p. 284; Appl. Catal., 55, 1989, p.115.

53. ASAFTEI, I. V., BILBA, N., SANDU, I., Rev. Chim., 65, no.4, 2014, p.431.

54. HAGEN A., ROESSNER, F., Stud. Surf. Sci. Catal., 98, 1995, p. 182.

55. FU, Z., YIN, D., YANG, Y., GUO, X., Appl. Catal. A: General, 124, No. 1, 1995, p. 59-71.

56. ASAFTEI, I.V., LUNGU, C.N., IGNAT, M., SANDU, I., Rev.Chim.,70, no.6, 2019, p. 2004.

57. ASAFTEI, V.I., BILBA, N., SANDU, I., Rev. Chim., 64, no.5, 2013, p.509.

58. ROJASOVA, E., SMIESKOVA, A., HUDEC, P., ZIDEK, Z., Collect. Czech. Chem. Commun., 65, No.9, 2000 , p. 1506.

59. BHATTACHARYA, D., SIVASANKER, S., Appl. Catal. A: General, 141, No. 1-2, 1996, p. 105.

60. ASAFTEI, I.V., LUNGU, N.C., BIRSA, L.M., SANDU, I.G., SARBU, L.G., IGANT, M., Rev. Chim., 68. no.1, 2017 p.116.

61. DAS, J., BHAT, Y.S., HALGERI, A.B., Stud. Surf. Sci. Catal., 113, 1998, p. 447.

62. ROESSNER, F., HAGEN, A., MROCZEK, U., KARGE, H.G., STEINBERG, K.H., Stud.

Surf. Sci. Catal., 75, 1993, p. 1707.

63. BISCARDI, J.A., MEITZNER, G.D., IGLESIA, E., J. Catal., 179, No. 1, 1998, p. 192.

64. HEEMSOTH, J., TEGELER, E., ROESSNER, F., HAGEN, A., Micropor. Mesopor. Mater., 46, 2001, p. 185.

65. Al-OTAIBI, N.M., HUTCHINGS, G., Catal. Lett., 134, No. 3-4, 2010, p. 191.

66. KOKES, R.J., DENT, A.L., Adv. Catal., 22, 1972, p.1.

67. ASAFTEI, I.V., LUNGU, N.C., SANDU, I., IGANT, M., Rev. Chim., 68, no. 4, 2017 p.715.

68. ONO, Y., KANAE, K., J. Chem. Soc., Faraday Trans., 87, 1991, p. 663.

69. JANA, A.K., RAO, M.S., Ind. Eng. Chem. Res., 32, 1993, p. 1046.

70. BERNDT, H., LIETZ, G., LÜCKE, B., VÖLTER, R., Appl. Catal. A: General, 146, No. 2, 1996, p. 351.

71. KWAK, B.S., SACHTLER, W.M.H., J. Catal., 145, No.2, 1994, p. 456.

72. NAGAMORI, Y., KAWASE, M., Micropor. Mesopor. Mater, 21, No. 4-6, 1998, p.439.

73. BISCARDI, J.A., IGLESIA, E., J. Catal., 182, no.1, 1999, p. 117; Phys. Chem. Chem. Phys., 1, 1999, p. 5753.

74. KAZANSKY, V.B., BOROVKOV, V.Yu., SERIKH, A.I., van SANTEN, R.A., ANDERSON, B.G., Catal. Lett., 66, 2000 , p. 39.

75. YU, S.Y., BISCARDI, J.A., IGLESIA, E., J. Phys.Chem. B, 106, No.37, 2002, p.9642.

76. LUBANGO, L.M., SCURRELL, M.S., Appl.Catal.A:General,235, No.1-2, 2002, p.265.

77. ASAFTEI, I.V.,SANDU, I.G., LUNGU, N. C., BARSA, L. M., SARBU, L. G., IGNAT, M., Rev. Chim., 67, no.5, 2016 , p.847.

78. DUFRESNE, L.A., Le van MAO, R., Catal. Lett., 25, No. 3-4, 1994, p. 371.

79. LI, Y., LIU, S., XIE, S., XU, L., Appl.Catal.A:General, 360, 2009, p.8.

80. ASAFTEI, I.V., ERAR, K., LUNGU, N.C., BIRSA, L.M., IGNAT, M., PLESU, V., SANDU, I.G., Rev. Chim. 67, no.4, 2016 p.734.

81. JOHNSON, J.A., WEISZMANN, J.A., HILDER, G.K., HALL, H.P., Paper presented at NPRA Annual Meeting, March 25-27, 1984, San Antonio, TX, USA; STEACY, P.C., US Patent 4528412 (1985), to UOP.

82. UOP LLC Cyclar ${ }^{\mathrm{TM}}$ Process. Des Plaines: UOP. 2001; http://www.uop.com/objects/46\%20Cyclar

83. TAMM, P.W., MOHR, D.H., WILSON, C.R., Stud. Surf. Sci. Catal., 38, 1988, p. 335.

84. UOP LLC. Rz - Platforming process. Des Plaines: UOP 1999.

85. CHEN, N.Y., YAN, T.Y., Ind. Eng. Chem. Process Des. Dev., 25, No. 1, 1986, p. 151.

86. CHEN, N.Y., GARWOOD, W.E., HECK, R.H., Ind. Eng. Chem. Res., 26, 1987, p.706.

87. ROVENSKAJA, S.A., OSTROVSKI, N.M., Chem. Ind., 57, No.9, 2003, p. 399.

88. BILBA,N., BILBA,D., VASILE,A., CRUCEANU, M., ABABI, V.,Brevet RO 96844, 1988.

89. OLSON, D.H., KOKOTAILO, G.T., LAWTON, S.L., MEIER, W.M., J. Phys. Chem., 85, 1981, p. 2238-2243.

90. HAAG, W.O., DESSAU, R.M., in: Proc. 8th Int. Congr. Catal., Berlin, Dechema, .2, 1984, p. 305.

Manuscript received: 14.02 .2020 
